\begin{tabular}{|c|c|c|}
\hline $\begin{array}{r}\text { Volume 1, Nomor 2, p 83-88 } \\
\text { Oktober 2017 }\end{array}$ & ISSN: 2502-6496 (Print) \\
\hline
\end{tabular}

RESEARCH ARTICLE

OPEN ACCESS

\title{
Evaluasi kualitas perairan Sungai Siak di wilayah Kota Pekanbaru berdasarkan kandungan nitrat, posfat dan kelimpahan diatom
}

\author{
Syifa Murtaja ${ }^{1}$, Bintal Amin $^{2}$, Thamrin ${ }^{2}$ \\ ${ }^{1}$ Alumni Pascasarjana Ilmu Lingkungan Universitas Riau. \\ ${ }^{2}$ Dosen Pascasarjana Ilmu Lingkungan Program Pascasarjana Universitas Riau.
}

\begin{abstract}
Sungai Siak waters is most commonly used by communities Pekanbaru for various activities such as water transportation, fisheries, agriculture, household, industrial and others. While these activities generate waste in the form of partial discharges would enter the river. The purpose of this study was to evaluate the quality of the waters of the Sungai Siak in the city of Pekanbaru based on the content of nitrate and phosphate. The results of measurements of nitrate in the Sungai Siak ranged from 0.2343 to $0.2771 \mathrm{mg} / \mathrm{l}$. Nitrate highest value at Station 4 is $0.3384 \mathrm{mg} / \mathrm{l}$ and the lowest at Station 1 is worth $0.2010 \mathrm{mg} / \mathrm{l}$. The content of phosphate in the Siak River which ranged from 1.3932 to $1.5170 \mathrm{mg} / \mathrm{l}$. Great relationship between nitrate with an abundance of diatoms were calculated by correlation coefficient (r) was 0.707 showed a strong association. Great relationship between phosphate with an abundance of diatoms were calculated by correlation coefficient $(r)$ was 0.728 showed a strong association.
\end{abstract}

Keywords: Nitrat; Phosphate; Abundance of diatoms; Sungai Siak.

Sungai Siak merupakan perairan yang paling banyak dimanfaatkan oleh masyarakat Pekanbaru untuk berbagai macam kegiatan seperti sarana transportasi air, perikanan, pertanian, keperluan rumah tangga, industri dan lain-lain. Selain itu juga Sungai Siak juga tempat penampungan berbagai macam limbah dari berbagai kegiatan industri, pertanian, perkebunan, perkotaan dan lain sebagainya mulai dari hulu sampai hilir. Sungai terdalam di Indonesia ini kondisinya mulai terancam, bukan hanya punah habitatnya, melainkan juga hilangnya sumber hayati perikanan akibat menurunnya kualitas air dan terjadinya abrasi (Suwondo et al., 2004).

Beberapa pencemaran Sungai Siak bersumber dari buangan limbah domestik dan industri. Beban pencemaran yang berasal dari limbah domestik memberikan kecenderungan peningkatan seiring dengan pertambahan jumlah penduduk yangterdapat pada DAS Siak. Sedangkan aktivitas industri ini menghasilkan buangan berupa limbah yang sebagian akan memasuki sungai. Kondisi tersebut menyebabkan terjadinya perubahan kualitas perairan Sungai Siak (Bapedal Provinsi Riau, 2013).

Perubahan kualitas air dapat dilihat dari nilai parameter fisika dan kimia pada perairan tersebut dengan acuan baku mutu Peraturan Pemerintah No. 82 Tahun 2001. Kesuburan suatu perairan dapat diketahui dari beberapa parameter seperti konsentrasi nitrat dan posfat serta kelimpahan diatomnya. Nitrat dan posfat merupakan unsur yang sangat penting dan merupakan faktor pembatas bagi produktivitas diatom yang merupakan unsur-unsur hara utama dan sangat dibutuhkan oleh diatom untuk tumbuh dan berkembang(Kasim dan Mukai, 2006). Diatom memiliki respon sangat cepat terhadap perubahan lingkungan dan memiliki waktu siklus hidup yang pendek dibandingkan dengan mikro invertebata lainnya (Masondalam Aprisanti, 2013).

Nitrat merupakan zat hara organik utama yang dibutuhkan oleh diatom untuk tumbuh dan kembangnya dengan baik. Nitrat merupakan bentuk senyawa nitrogen yang bersifat stabil dan mudah larut. Menurut Boney (1975) besarnya kandungan nitrat yang ada dalam perairan akan merangsang pertumbuhan bagi diatom, karena kandungan nitrat pada konsentrasi tertentu akan memberikan kondisi tumbuh yang baik bagi diatom dan dapat menjadi racun di perairan apabila konsentrasi melebihi yang dibutuhkan.

Posfat merupakan bentuk posfor yang dapat dimanfaatkan oleh tumbuhan. Posfat sangat diperlukan sebagai transfer energi dari luar kedalam sel organisme. Bila kadar posfat sangat rendah (kurang dari 0,01 $\mathrm{mg} / \mathrm{l}$ ) pertumbuhan ganggang akan terhalang (oligotropik) dan jika kadar posfat dan nutrien lain tinggi (lebih dari $1 \mathrm{mg} / \mathrm{l}$ ) maka pertumbuhan ganggang menjadi tidak terbatas (eutropik) sehingga hal tersebut dapat menghabiskan oksigen dalam perairan (Effendi, 2012).

Pertumbuhan diatom sangat ditentukan oleh nutrien dan cahaya. Pada umumnya diatom bergerak aktif secara vertikal mendekati sinar matahari.Keberadaan diatom sangat penting, dimana diatom sebagai 
produsen primer yang berperan dalam menyediakan oksigen dan sebagi sumber makanan bagi organisme lainnya(Cloern dan Jassby, 2010).

Melihat adanya permasalahan yang terdapat di perairan Sungai Siak di Kota Pekanbaru ini, maka peneliti tertarik untuk melakukan evaluasi kualitas perairan Sungai Siak di Kota Pekanbaru dengan melihat kualitas air berdasarkan parameter fisika dan kimia serta kelimpahan diatom dalam perairan tersebut.

\section{METODE PENELITIAN}

Pelaksanaan penelitian dilakukan bulan April 2015 yang berlokasi di Sungai Siak Kota Pekanbaru. Pengukuran kualitas air dilakukan langsung di lapangan dan di laboratorium. Analisis sampel kualitas air (parameter fisika, kimia dan biologi) dilakukan di Laboratorium Ekologi Fakultas Perikanan dan Ilmu Kelautan Universitas Riau.

Peralatan yang digunakan dibedakan menjadi dua yaitu peralatan lapangan dan peralatan laboratorium. Peralatan lapangan meliputi: Termometer air raksa untuk mengukur suhu perairan, secci disk untuk mengukur kecerahan, current drogue untuk mengukur kecepatan arus, $\mathrm{pH}$ meter untuk menentukan nilai $\mathrm{pH}$, kertas label, botol sampel kapasitas 1 liter, plastik, pipet tetes dan ice box. Peralatan laboratorium meliputi alat-alat gelas/tabung reaksi, buret untuk titrasi, kertas saring Whatman no.42, timbangan analitik, alat pemanas (hotplate), oven gelas ukur, gelas beaker, labu takar, kaca arloji dan pengaduk. Bahan yang digunakan dalam penelitian ini adalah sampel air, larutan $\mathrm{H}_{2} \mathrm{SO}_{4}$ pekat, dan lugol.

Metode yang digunakan dalam penelitian ini adalah metode survei, yaitu melakukan pengamatan langsung di perairan Sungai SiakKota Pekanbaru. Penentuan Stasiun pengamatan secara purposive sampling yaitu dengan memperhatikan berbagai pertimbangan kondisi serta keadaan daerah penelitian yang mempunyai karakteristik lingkungan yang berbeda yang dianggap dapat mewakili kondisi perairan Sungai Siak di Kota Pekanbaru secara keseluruhan. Pengambilan sampel dan pengukuran kualitas air terdiri dari empat Stasiun dimana tiap Stasiun-stasiun terdiri dari tiga sub stasiun dengan jarak masing masing sekitar 10 meter.

Stasiun 1 :pada sebelah hulusebelum lokasi industri pabrik karet, untuk mengetahui kualitas perairan sebelum dipengaruhi oleh air limbah yang terletak 500 meter dari Stasiun 2.

Stasiun 2 : pada sekitar lokasi industri pabrik karet.

Stasiun 3 : pada sebelah hilirsetelah lokasi industri pabrik karet dan sebelum industri pabrik kayu yang terletak 1000 meter dari Stasiun 2.

Stasiun 4 : pada sekitar lokasi industri PT. Pertamina yang terletak 1500 meter dari Stasiun 3.

Untuk menganalisis data kualitas perairan (parameter Fisika dan Kimia) di Sungai Siak di Kota Pekanbaru berdasarkan kelas mengacu pada ketetapan pemerintah yang berhubungan dengan perairan sungai. Dalam hal ini tingkat yang menunjukkan kondisi tercemar atau baik pada suatu sumber air dengan membandingkan terhadap baku mutu air yang ditetapkan. Baku mutu dan peruntukan kualitas air yang dipakai dalam penelitian ini adalah Peraturan Pemerintah No. 82 Tahun 2001.

Untuk menentukan pengaruh dari aktivitas masyarakat dan industri terhadap distribusi nitrat dan posfat di sekitar perairan Sungai Siak di kota Pekanbaru dengan kelimpahan diatom di masing-masing stasiun digunakan uji Anova satu arah (Priyatno, 2012).

Untuk menentukan hubungan kosentrasi nitrat atau posfat dengan kelimpahan diatom digunakan model regresi parsial. Besarnya pengaruh kosentrasi nitrat atau fosfat dengan kelimpahan diatom di tentukan dengankoefisien determinasi $\left(\mathrm{R}^{2}\right)$. Untuk mengetahui kuat tidaknya hubungan kosentrasi nitrat dan pospat dengan kelimpahan diatom dinyatakan dengan koefisien korelasi (r). Nilai $r$ berkisar -1 sampai +1 , bila $\mathrm{r}$ bernilai positif berarti variabel-variabel itu mempunyai hubungan positif begitu pula sebaliknya.

\section{HASIL DAN PEMBAHASAN}

Kota Pekanbaru sebagai Ibukota Propinsi Riau terletak pada koordinat $101^{0} 14^{\prime}-101^{0} 34^{\prime} \mathrm{BT}$ dan $0^{0}$ $25^{\prime}-0^{0} 45^{\prime}$ LU dengan luas batas administrasi wilayah antara lain sebelah Utara dengan Kabupaten Siak, Selatan dengan Kabupaten Kampar, Timur dengan Kabupaten Pelalawan, dan Barat dengan Kabupaten Kampar.

Parameter kualitas perairan merupakan faktor yang sangat mempengaruhi kehidupan di dalam air Sungai Siak. Parameter yang diukur untuk menentukan kualitas perairan Sungai Siak meliputi parameter fisika yaitu suhu, kecerahan, kecepatan arus, TSS, sedangkan parameter kimia yang diukur yaitu $\mathrm{pH}$, $\mathrm{COD}, \mathrm{BOD}$, nitrat, pospat dan parameter biologi yaitu kelimpahan diatom. 


\section{Parameter Fisika}

Suhu

Suhu merupakan salah satu faktor yang sangat penting bagi kehidupan dan pertumbuhan biota air. Suhu perairan Sungai Siak yang diukur secara langsung dilapangan berkisar $30,5-30,7^{\circ} \mathrm{C}$. Menurut Huet (1975) kisaran suhu yang layak untuk kehidupan didalam air tawar berkisar antara 20-30 ${ }^{\circ} \mathrm{C}$ dengan suhu optimum berkisar antara $35-40{ }^{\circ} \mathrm{C}$. Jika mengacu pada baku mutu Peraturan Pemerintah No. 82 Tahun 2001 mengenai kualitas air sungai $27-30{ }^{\circ} \mathrm{C}$ kisaran tersebut masih relatif stabil dalam kisaran pertumbuhan biota air.

Menurut Kasry (2012), Adanya variasi nilai suhu di sungai siak disebabkan oleh perbedaan waktu pengukuran, cuaca yang cukup panas pada waktu pengukuran, serta lokasi sampling yang agak dangkal, sehingga memberikan pengaruh pada pemanasan cahaya matahari dapat mencapai dasar perairan. Menurut Efriyeldi (2005), dangkalnya perairan menyebabkan pengaruh pemanasan cahaya matahari dapat mencapai dasar perairan. Dibandingkan dengan hasil-hasil penelitian sebelumnya, kisaran nilai suhu di Sungai Siak tidak jauh berbeda, misalnya hasil pengkuran Surya (2010) berkisar $28-29^{\circ} \mathrm{C}$, Purnamasari (2010) berkisar $28-29^{\circ} \mathrm{C}$ dan Muharram (2008) berkisar 28,6-30,6 ${ }^{\circ} \mathrm{C}$.

\section{Kecerahan}

Kecerahan merupakan yang sangat menentukan tingkat produtivitas primer perairan. Berdasarkan hasil pengukuran, didapati kecerahan berkisar 31,5-38,5 cm. Menurut Cholik et al. (1986) kecerahan yang produktif berkisar antara 30-60 cm. Hal tersebut berati nilai kecerahan yang terukur sudah cukup sesuai untuk perkembangan biota air. Kecerahan yang tinggi menyebabkan sinar matahari yang masuk kedalam perairan semakin tinggi. Tingginya intensitas sinar matahari biasanya disebabkan oleh partikel-partikel terlarut dan padatan tersuspensi dalam perairan sehingga daya tembus sinar matahari tinggi.

Menurut Effendi (2003) faktor yang mempengaruhi nilai kecerahan adalah keadaan cuaca, waktu pengukuran, kekeruhan dan padatan tersuspensi serta ketelitian pengukuran. Jika dibandingkan dengan beberapa hasil penelitian sebelumnya seperti Kasry (2012) dengan nilai kecerahan berkisar 22,16-32,53 cm dan Purba (2011) berkisar 26,25-32,75 cm, maka nilai kecerahan di perairan Sungai Siak relatif tidak jauh berbeda.

\section{Kecepatan Arus}

Arus permukaan berperan penting dalam persebaran biota air karena arus berpengaruh terhadap distribusi organisme dan mineral yang terdapat dalam air. Menurut Harahap (1999) Kecepatan arus dapat dibedakan empat katagori yaitu: 1) Kecepatan arus 0-25 cm/det merupakan arus lambat; 2) Kecepatan arus 25-50 cm/det merupakan arus sedang; 3) Kecepatan arus 50-100 cm/det merupakan arus cepat; 4) Kecepatan arus $>100 \mathrm{~cm} /$ det merupakan arus sangat cepat. Kecepatan arus yang didapatkan pada penelitian ini berkisar antara 0,25-0,50 m/det yaitu relatif sedang.

Kecepatan arus badan air sungai siak sangat berpengaruh terhadap kemampuannya dalam mengasimilasi dan mengangkut bahan pencemar. Besarnya arus sungai dapat mempengaruhi jenis substrat di setiap tempat. Stasiun $1-4$ sungai siak memiliki kecepatan arus sedang dicirikan jenis substrat yang berbatu dan berlumpur.

\section{Total Suspended Solid (TSS)}

Hasil pengamatan terhadap TSS di perairan Sungai Siak menunjukkan bahwa nilai TSS perairan berkisar antara 1-7 mg/. Nilai TSS ini masih berada di bawah ambang batas yang ditetapkan oleh Peraturan Pemerintah No. 82 tahun 2001, yaitu $50 \mathrm{mg} / 1$. Nilai TSS perairan sungai Siak dapat dikategorikan masih layak bagi kehidupan organisme.Total Suspended Solid (TSS) ini merupakan parameter fisika kualitas air yang berkaitan erat dengan kekeruhan, dimana nilai TSS akan berbanding lurus dengan nilai kekeruhan. Effendie (2003) mengatakan bahwa semakin tinggi nilai kekeruhan, maka nilai kelarutan zat-zat tersuspensi juga akan tinggi.

Banyaknya partikel-partikel yang melayang-layang di perairan seperti tanah, lumpur, detritus, pasir, buangan limbah domestik dan lainnya dapat menghambat sinar matahari masuk ke perairan yang dapat mengurangi kemampuan diatom untuk melakukan fotosintesis. Dengan demikian kandungan $\mathrm{O}_{2}$ terlarut juga akan berkurang yang merupakan hasil dari fotosintesis diatom.

\section{Parameter Kimia \\ Derajat Keasaman (pH)}

Derajat keasaman $(\mathrm{pH})$ Sungai Siak hasil pengukuran dari hasil tiap Stasiun berkisar antara 5-6 dimana $\mathrm{pH}$ tertinggi terlihat pada Stasiun 1 dan Stasiun 3 dan yang terendah terlihat Stasiun 2 dan Stasiun 4 seperti yangditunjukkan Gambar 5. Berdasarkan PP No. 82 tahun 2001 kelas III bahwa pH perairan Sungai Siakpada Stasiun 1 dan 3 masih dibawah ambang batas diduga karena jauh dari aktivitas industri 
dan masih banyak vegetasi yang hidup pada Stasiun 1 dan 3 sedangkan pada Stasiun 2 dan 4telah melewati nilai ambang batas baku mutu kualitas air yang disebabkan oleh adanya aktivitas industri pabrik karet pada Stasiun 2 dan PT.Pertamina di Stasiun 4.

Sesuai dengan pernyataan Ginting (2011) yaitu perubahan $\mathrm{pH}$ bisa dipengaruhi oleh adanya buangan senyawa-senyawa yang masuk kedalam lingkungan perairan. Menurut Kordi dan Tancung (2005) bahwa tinggi rendahnya $\mathrm{pH}$ perairan dapat juga dipengaruhi oleh kandungan $\mathrm{CO}_{2}$ bebas dan tanah dasar. Nilai $\mathrm{pH}$ di perairan berbanding terbalik dengan kandungan $\mathrm{CO}_{2}$ bebas di perairan, sehingga pada saat kandungan $\mathrm{CO}_{2}$ bebas meningkat, maka $\mathrm{pH}$ akan turun dan sebaliknya. $\mathrm{pH}$ Sungai Siak yang diukur pada saat pengamatan yang dilakukan termasuk asam. Selain disebabkan oleh kandungan $\mathrm{CO}_{2}$ bebas, $\mathrm{pH}$ Sungai Siak juga disebabkan oleh tanah yang bersifat asam.

\section{Biological Oxygen Demand $\left(\mathrm{BOD}_{5}\right)$}

Nilai BOD tertinggi terdapat pada stasiun 4 yaitu $1,5 \mathrm{mg} / 1$ dan terendah pada stasiun 1 yaitu0,47 $\mathrm{mg} / 1$ seperti yang ditunjukkan pada Gambar 6 . Tingginya nilai BOD, dikarenakan bahan-bahan organik yang berasal dari limbah aktivitas manusia yang masuk ke Sungai Siak lebih banyak. Sehingga jumlah $\mathrm{O}_{2}$ yang dibutuhkan untuk mengoksidasi bahan-bahan organik lebih besar. Sebaliknya rendahnya nilai BOD, dikarenakan bahan-bahan organik yang berasal dari limbah aktivitas manusia yang masuk ke Sungai relatif sedikit. Sehingga jumlah $\mathrm{O}_{2}$ yang dibutuhkan untuk mengoksidasi bahan-bahan tersebut juga sedikit.

Berdasarkan hasil yang diperoleh dari nilai BOD5 didapat bahwa perairan sungai Siak merupakan perairan yang tidak tercemar dimana nilai BOD5 $\leq 1,5 \mathrm{mg} / 1$. Konsentrasi BOD sangat penting dalam pengelolaan limbah dan pengelolaan kualitas air, karena parameter ini dapat digunakan untuk memperkirakan jumlah oksigen yang akan dibutuhkan untuk menstabilkan buangan organik yang ada secara biologis dalam suatu perairan. Hal ini sesuai dengan pernyataan Fadil (2011) bahwa tingkat pencemaran suatu perairan dapat dinilai berdasarkan kandungan nilai BOD5 dimana kandungan $\leq 2,9$ $\mathrm{mg} / \mathrm{l}$ merupakan perairan yang tidak tercemar.

\section{Chemical Oxygen Demand (COD)}

Kandungan COD di Sungai Siakdari pengamatan berkisar antara 16,0-54,4 mg/1. Nilai COD tertinggi di stasiun 2 yaitu 54,4dan pengamatan sangat rendahpada stasiun 4 Nilai COD 16,0.Berdasarkan PP No. 82 tahun 2001 nilai COD pada Stasiun 2diatas ambang batas baku mutu dan masuk kriteria mutu air kelas IIIini menunjukkan bahwa pada wilayah tersebut banyak terdapat zat organik.

Nilai COD ditentukan oleh faktor buanganyang dapat teroksidasi melalui reaksi kimia dan menggunakan oksigen yang terdapat di perairan tersebut. Bila kandungan COD-nya tinggimaka nilai DOnya akan semakin rendah karena pada daerah ini nilai kecukupan oksigennya tidak memadai.

\section{Nitrat (N)}

Hasil pengukuran nitrat di Sungai Siak yang diperoleh berkisar antara 0,2343 - 0,2771 mg/1. Nilai nitrat yang tertinggi pada Stasiun 4 yaitu $0,3384 \mathrm{mg} / 1$ dan terendah pada Stasiun 1yaitu senilai 0,2010 $\mathrm{mg} / 1$.Dari hasil uji Anova konsentrasi nitrat pada setiap stasiun berbeda nyata $(\mathrm{p}<0,05)$ dengan nilai signifikansi $0,03<0,05$ yang menunjukkan bahwa adanya pengaruh dari aktivitas masyarakat dan industri di sekitar Sungai Siak pada tiap Stasiun terhadap konsentrasi nitrat.

Konsentrasi nitrat tinggi di sungai Siak merupakan hasil oksidasi dari amonium dan amoniak yang berasal dari limbah domestik. Keberadaan Sungai Siak pada lokasi yang dekat dengan aktivitas penduduk menyebabkan buangan limbah domestik yang banyak mengandung amoniak akan mempengaruhi konsentrasi nitrat. Menurut Yazwar (2008), bahwa nitrat merupakan hasil oksidasi terakhir dari amonium dan amoniak yang berasal dari limbah domestik. Buangan limbah domestik yang mengandung amoniak menyebabkan meningkatnya kandungan nitrat. Budiharjo dan Huboyo (2007) menyatakan sumber polutan seperti nitrat yang berasal dari perairan mempunyai jumlah lebih sedikit dibandingkan yang berasal dari aktivitas manusia.

\section{Posfat (P)}

Posfat merupakan salah satu unsur penting dalam perairan untuk proses metabolisme sel organisme. Di perairan unsur posfor terdapat dalam senyawa posfat yang berada dalam bentuk organik dan anorganik (Rukhoyah, 2005). Kandungan posfat di Sungai Siak yang diamati pada saat praktikum berkisar antara $1,3932-1,5170 \mathrm{mg} / 1$. Dari hasil uji Anova konsentrasi posfat berbeda nyata $(\mathrm{p}<0,05)$ pada dengan nilai signifikansi $0,01<0,05$ yang menunjukkan perbedaan yang nyata pada masing-masing Stasiun.

Hal ini sesuai dengan pendapat Effendie (2003) yang menyatakan bahwa kandungan posfat di perairan berasal dari limbah industri dan limbah domestik yakni posfor yang berasal dari detergen. 
Limpasan dari daerah pertanian yang menggunakan pupuk juga memberikan kontribusi yang cukup besar bagi keberadaan posfat. Semakin kearah hilir kandungan nilai posfat semakin tinggi. Berdasarkan PP No. 82 tahun 2001 nilai posfat pada penelitian ini di atas ambang baku mutu dan termasuk kriteria mutu air sungai kelas IV.

\section{Parameter Biologi}

\section{Kelimpahan Diatom}

Diatom yang teridentifikasi di perairan Sungai Siak terdapat 6 Spesies dan pada semua Stasiun terdiri dari jenis yang sama yaitu Achnanthes sp,Coscinodinodiscus sp, Cyclotella sp dan Melosira sp. Namun ada 2 jenis yang tidak terdapat pada semua Stasiun yaitu Denticulopsis sp dan Eunotia sp.Dari hasil uji Anova kelimpahan diatom berbeda nyata $(\mathrm{p}<0,05)$ pada dengan nilai signifikansi $0,000<0,05$ yang menunjukkan ada pengaruh aksivitas masyarakat dan industri di setiap Stasiun terhadap kelimpahan diatom.

\section{Hubungan Kandungan Nirat dan Posfatdengan Kelimpahan Diatom}

Berdasarkan hasil penelitian hubungan kandungan nitrat dan posfatdengan kelimpahan diatom di perairan Sungai Siak di Kota Pekanbaru dapat dilihat pada Gambar 1 dan 2.

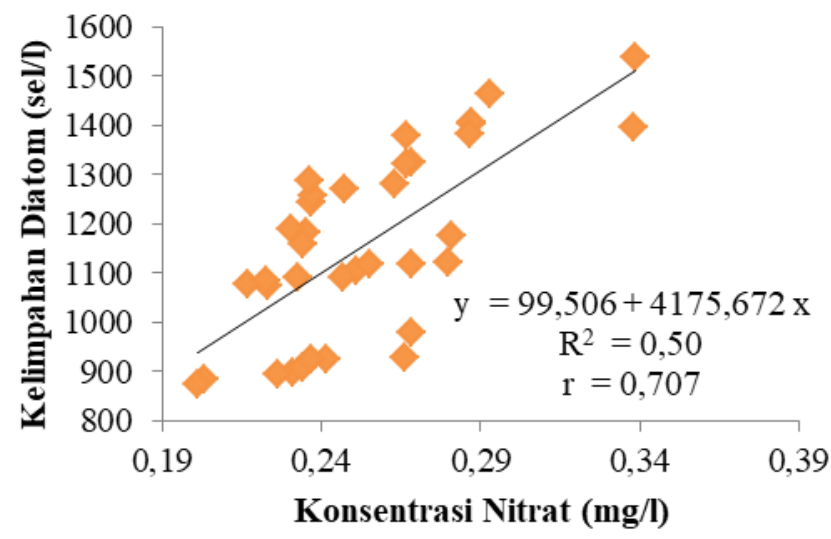

Gambar1. Hubungan kandungan nitrat dengan kelimpahan diatom

Berdasarkan hasil analisisregresi linier sederhana untuk hubungan kosentrasi nitrat dengan kelimpahan diatom dengan persamaan regresinya $\mathrm{Y}=99,506+4175,672 \mathrm{x}$ berarti hubungan positif artinya semakin tinggi konsentrasi nitrat maka semakin tinggi kelimpahan diatom dan determinasi $\left(\mathrm{R}^{2}\right)$ sebesar 0,50 artinya ada pengaruh nitrat terhadap kelimpahan diatom diperairan Sungai Siak sebesar $50 \%$. Besar hubungan antara nitrat dengan kelimpahan diatomyang dihitung dengan koefisien kolerasi $(r)$ adalah 0,707. Hal ini menunjukkan hubungan kuat karena berkisar antara 0,71 - 0,90 (Razak, 1991).

Hubungan kuat ini juga di temukan oleh penelitian Zulkarnain (2013) hal tersebut dikarenakan nitrat merupakan unsur hara utama yang dimanfaatkan oleh diatom. Keadaan kecepatan arus yang sedang di setiap Stasiunnya dapat mempengaruhi pergerakan yang menyebarkan nutrien dan diatom yang dapat mempengaruhi kuatnya hubungan antara nitrat dengan kelimpahan diatom.

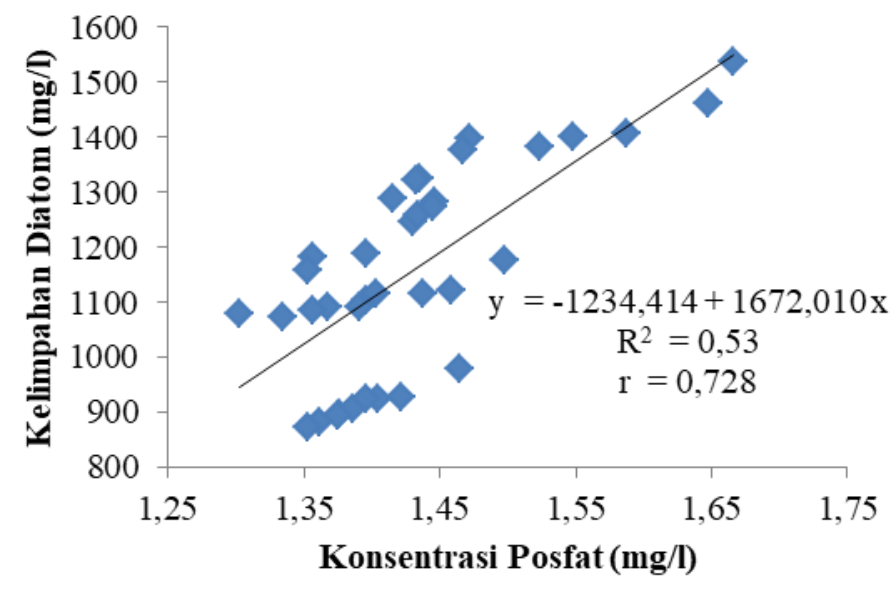

Gambar 2. Hubungan kandungan posfat dengan kelimpahan diatom. 
Hasil uji regresi linier sederhana untuk hubungan konsentrasi posfat dengan kelimpahan diatom dengan persamaan regresinya $\mathrm{Y}=-1234,414+1672,010 \mathrm{x}$ berarti hubungan positifartinya semakin tinggi konsentrasi posfat maka semakin tinggi kelimpahan diatom. Posfat merupakan unsur hara yang sangat penting dalam metabolisme diatom. Posfat sangat diperlukan sebagai transfer energi dari luar kedalam sel organisme, oleh karena itu posfat yang dibutuhkan hanya dalam jumlah yang sedikit (Effendi, 2003). Kandungan posfor di Sungai Siak dalam penelitian inidiatas ambang bakumutu dan termasuk kriteria mutu air kelas IV yang diduga mengakibatkan hubungan negatif antara konsentrasi posfat dengan kelimpahan diatom.

Determinasi $\left(\mathrm{R}^{2}\right)$ sebesar 0,53 artinya ada pengaruh posfat terhadap kelimpahan diatom diperairan Sungai Siak sebesar 53\% (Lampiran 8). Besar hubungan antara posfat dengan kelimpahan diatomyang dihitung dengan koefisien kolerasi ( $r$ ) adalah 0,728 . Hal ini menunjukkan hubungan kuat karena berkisar antara $0,71-0,90$ (Razak 1991).

\section{KESIMPULAN}

Berdasarkan hasil penelitian yang dilakukan di perairan Sungai Siak di Kota Pekanbaru menurut PP No.82 Tahun 2001 Derajat keasaman $(\mathrm{pH})$ pada Stasiun 2 dan 4 berada di atas ambang batas baku mutu dan COD pada Stasiun 1, 2 dan 3 melebihi baku mutu pada Stasiun 1 dan 3 berada pada kelas III dan Stasiun 2 berada pada kelas IV dan kandungan posfat di setiap Stasiun melebihi baku mutu berada pada kelas IV. Berdasarkan uji wan way anova terdapat perbedaan yang nyata konsentrasi nitrat, posfat dan kelimpahan diatom pada masing-masing Stasiun dan dari uji regresi searah konsentrasi nitrat dan posfat menunjukkan hubungan yang kuat dengan kelimpahan diatom di perairan Sungai Siak di wilayah Kota Pekanbaru.

\section{UCAPAN TERIMAKASIH}

Penulis mengucapkan terimakasih kepada Allah SWT atas rahmat Nya, sehingga penelitian ini terlaksana dengan baik. Demikian pula atas dukungan semua pihak yang berkaitan dengan penelitian ini.

\section{DAFTAR PUSTAKA}

Aprisanti, R. A, Mulyadi dan S H Siregar. 2013. Struktur Komunitas Diatom Epilitik Perairan Sungai Senapelan dan Sungai Sail Kota Pekanbaru. Laporan Penelitian. Lembaga Penelitian Universitas Riau.

Bapedal. 2013. Pengukuran Parameter Kualitas Air Perairan Sungai Siak. Pekanbaru.

Cloern, J. E., Jassby, A. D. 2010. Patterns and Scales Phytoplankton Variability In Estuarine-Coastal Ecosystem. Estuaries and Coasts, 33 (2): 230- 241.

Effendi, H. 2012. Telaah Kualitas Air Bagi Pengelolaan Sumber Daya dan Lingkungan Perairan. Kanisus. Yogyakarta.

Efriyeldi. 2002. Struktur Komunitas Makrozoobenthos di Perairan Sekitar Budidaya Ikan Kakap dalam Keramba Jaring Apung. Berkala Perikanan Terubuk 29 (4) : 5-10.

Fadil. M. S. 2011. Kajian Beberapa Aspek Parameter Fisika Kimia Air dan Aspek Fisiologis Ikan Yang Ditemukan Pada Aliran Buangan Pabrik Karet di Sungai Batang Arau. Program Studi Biologi Pascasarjana Universitas Andalas.

Kasim, M. dan Mukai, H., 2006 Contribution of Benthic and Epiphytic Diatoms to Clam and Oyster Production in the Akkeshi-ko Estuary. Journal of Oceanography, Vol. 62, pp. 267 to 281. Hokkaido University. Japan.

Kasry. A, dan N E Fajril. 2012. Kualitas Perairan Muara Sungai Siak ditinjau dari Parameter Fisik-Kimia dan Organisme Plankton. Universitas Riau Berkala Perikanan Terubuk, 40 (2) :96 - 113

Suwondo, Febrita, E., Dessy dan M. Alpusari. 2004. Kualitas Biologi Perairan Sungai Senapelan, Sago dan Sail di Kota Pekanbaru Berdasarkan Bioindikator Planton dan Bentos. Jurnal Biogenesis Vol. 1:15-20 Universitas Riau. Pekanbaru. 